\title{
Pertumbuhan Kepiting Bakau (Scylla serrata Forsskål, 1775) dengan Ukuran Pakan Berbeda pada Budidaya dengan Sistem Baterai
}

\author{
Ali Djunaedi*, Sunaryo dan Bagus Pitra Aditya \\ Jurusan IImu Kelautan, Fakultas Perikanan dan IImu Kelautan, Universitas Diponegoro. \\ JI. Prof. Soedarto, SH. Kampus UNDIP Tembalang, Semarang 50275 \\ E-mail : alidjunaedi@ymail.com
}

\begin{abstract}
Abstrak
Kepiting bakau (S. serrata Forsskål, 1775) merupakan salah satu sumber daya perikanan bernilai ekonomis tinggi dan potensial untuk dibudidayakan. Pakan adalah faktor produksi yang penting dalam budidaya kepiting bakau. Tujuan dari penelitian ini adalah untuk mengetahui pengaruh pemberian pelet yang berbeda ukuran bagi pertumbuhan kepiting bakau (S. serrata Forsskål, 1775). Metode penelitian ini menggunakkan Rancangan Acak Lengkap (RAL) dengan 3 perlakuan dan 10 kali ulangan pada masing-masing perlakuan, yaitu: perlakuan A (diameter pelet $\pm 10 \mathrm{~mm}$ ), perlakuan B (diameter pelet $\pm 5 \mathrm{~mm}$ ) dan perlakuan $C$ (diameter pelet $\pm 1 \mathrm{~mm}$ ). Data laju pertumbuhan spesifik $(S G R)$ dianalisis dengan Anova. Hasil penelitian menunjukkan bahwa perlakuan pemberian pelet yang berbeda ukuran berpengaruh sangat nyata $(p \leq 0,01)$ terhadap Laju Pertumbuhan Spesifik (SGR), Rasio Konversi Pakan (FCR) dan Rasio Efisiensi Protein (PER). Hal tersebut menunjukkan bahwa ukuran pellet sangat menentukan pertumbuhan Kepiting Bakau (S. serrata Forsskål, 1775).
\end{abstract}

Kata Kunci : Ukuran Pelet, Kepiting Bakau (S. serrata Forsskål, 1775), Laju Pertumbuhan Spesifik (SGR)

\begin{abstract}
Mud crab (S. serrata Forsskål, 1775) is one of the fisheries resources that has high economic value and potential to be cultivated. Feed is one of important production factors on the mud crab farming. The purpose of this study is investigated the effect of different sizes pellets on the growth of mud crab (S. serrata Forsskål, 1775). The research method in this study was used experimental laboratory with completely randomized design (CRD) with 3 treatments and 10 replications in each treatment. Specific growthrate (SGR) data was analyzed with anova. These results indicate that administration of treatment different size pellets effect is very significant $(p \leq 0,01)$ on Specifik Growthrate (SGR), Feed Conversion Ratio (FCR) and Protein Efiecient Ratio (PER). Its that suggest that pellet size affect on the growthrate of the mud crab (S. serrata Forsskål, 1775).
\end{abstract}

Keywords: Pellet Size, Mud crab (S. serrata Forsskål, 1775), Specific growth rate (SGR)

\section{PENDAHULUAN}

Kepiting bakau (Scylla serrata Forsskål, 1775) merupakan salah satu sumber daya perikanan bernilai ekonomis tinggi dan potensial untuk dibudidayakan. Potensi pasar kepiting bakau tidak hanya di dalam negeri, tetapi di luar negeri juga cukup besar. Hal ini memberikan peluang pengembangan komoditas kepiting bakau secara lebih maju. Pemenuhan kebutuhan kepiting bakau melalui intensifikasi penangkapan secara besar-besaran akan mengakibatkan penurunan populasi bahkan kelangkaan kepiting bakau di alam. Melihat kondisi tersebut perlu 
dilakukan usaha budidaya kepiting bakau secara intensif, sehingga dapat menghasilkan kepiting bakau yang berkesinambungan.

Permasalahan yang dihadapi dalam budidaya kepiting bakau (S. serrata Forsskål, 1775), antara lain : laju pertumbuhan yang relatif lambat, kanibalisme, pakan, penyakit, dan buruknya kualitas air (Overton dan Pushpakumara, 2003). Laju pertumbuhan yang relatif lambat akan berpengaruh langsung terhadap lamanya waktu pemeliharaan kepiting bakau, sehingga jumlah pakan yang diberikan semakin banyak.

Penelitian untuk meningkatkan laju pertumbuhan pada budidaya kepiting bakau dengan berbagai metode sudah dilakukan oleh beberapa peneliti, seperti pemberian salinitas yang berbeda terhadap konsumsi pakan kepiting bakau (Karim, 2007), pemberian pakan dengan komposisi dan ransum harian berbeda terhadap kematangan gonad kepiting bakau (Djunaedi, 2008), padat tebar yang berbeda terhadap pertumbuhan dan kelangsungan hidup pada penggemukan kepiting bakau (Fadnan et al., 2010) dan lain-lain.

Pakan merupakan salah satu faktor yang harus dipenuhi untuk mencapai produksi yang maksimal dalam budidaya kepiting bakau. Pakan tersebut harus memenuhi persyaratan antara lain, penyediaannya, pengolahannya, Kandungan gizinya, maupun pertimbangan sesuai tidaknya dengan pola kebiasaan makan kepiting bakau. Penggunaan pakan ikan rucah sampai saat ini masih dianggap lebih menguntungkan karena harganya relative lebih murah. Akan tetapi permasalahan dalam penyediaan ikan rucah, yaitu adanya kompetisi dengan kebutuhan manusia, pengaruh musim dan masa simpan yang pendek serta kualitasnya yang bervariasi. Permasalahan tersebut perlu diatasi dengan pakan alternatif, yaitu penyediaan pakan buatan berupa pelet dengan kandungan gizi dan ukuran yang sesuai.
Penggunaan pelet sebagai pakan buatan telah banyak dilakukan, tetapi hasilnya masih jauh dari apa yang diharapkan. Menurut Aslamyah dan Fujaya (2009), pakan buatan yang diberikan pada kepiting bakau biasanya berupa pelet untuk udang. Pakan tersebut berukuran relatif lebih kecil, sehingga diduga tidak dapat dimanfaatkan secara baik dan belum sesuai dengan pola kebiasaan makan kepiting bakau. Kondisi ini mengakibatkan masih banyak sisa pakan yang terbuang, sehingga dapat menurunkan kualitas air media pemeliharaan. Kanna (2005) menyatakan bahwa ukuran pakan perlu disesuaikan dengan kemampuan kepiting bakau dalam mencapit makanan.

Berdasarkan hal tersebut, perlu dilakukan kajian tentang penggunaan berbagai ukuran pelet yang sesuai dengan pola kebiasaan makan kepiting bakau, sehingga dapat menunjang laju pertumbuhan kepiting bakau.

\section{MATERI DAN METODE}

Hewan uji yang digunakan untuk penelitian adalah 30 ekor kepiting bakau (S. serrata Forsskål, 1775) berjenis kelamin jantan. Biota uji dipilih didasarkan pada kesehatan, kelengkapan organ tubuhnya dan ukuran berat $50-55 \mathrm{~g}$. Media uji yang digunakan berupa air laut bersalinitas 20 g/L.

Pakan uji dibuat dari repelleting pakan komersial udang dalam bentuk pelet yang mengandung protein min $32,0 \%$, lemak min $6,0 \%$, serat kasar maks $3,0 \%$, abu maks $18,0 \%$, kadar air maks $11 \%$. Pakan uji ini diperoleh dari BBPBAP (Balai Besar Pengembangan Budidaya Air Payau), Jepara. Pemberian pakan dilakukan setiap hari dengan jumlah $10 \%$ dari berat tubuhnya (Susanto, 2008). Sedangkan Wadah uji yang digunakan selama penelitian berupa bak fiber, volume 500 liter sebanyak 3 buah dan ember cat bekas berbentuk silinder atau tabung sebagai wadah hewan uji secara individu dengan diameter $20 \mathrm{~cm}$ dan tinggi $25 \mathrm{~cm}$ 
sebanyak 30 buah. Pada sisi ember dilubangi, $4 \mathrm{~cm}$ di atas dasar tabung sebanyak 24 lubang.

Penelitian ini menggunakan metode eksprimental laboratories dan Rancangan percobaan yang digunakan adalah Rancangan Acak Lengkap (RAL) menggunakan tiga perlakuan dengan pemberian pakan komersial berupa pelet udang yang berbeda ukuran dan masingmasing perlakuan diulang sebanyak sepuluh kali. Perlakuan A, pemberian pakan pelet dengan diameter $(\varnothing)$ pakan \pm $10 \mathrm{~mm}$, Perlakuan $B$, diameter $(\varnothing)$ pakan \pm $5 \mathrm{~mm}$ dan Perlakuan $C$, diameter $(\varnothing)$ pakan $\pm 1 \mathrm{~mm}$.

\section{HASIL DAN PEMBAHASAN}

\section{Pencapaian Berat}

Data rerata pencapaian berat kepiting bakau (S. serrata Forsskål, 1775) selama 35 hari (5 minggu) pada masingmasing perlakuan mengalami peningkatan setiap minggunya. Respon pencapaian berat yang tertinggi dicapai pada Perlakuan A yaitu $72,60 \pm 5,32 \mathrm{~g}$, selanjutnya perlakuan B yaitu $70,15 \pm 4,10 \mathrm{~g}$, dan yang paling rendah dicapai pada perlakuan $C$ yaitu 62,38+2,41 g (Gambar 1).

\section{Laju Pertumbuhan Spesifik}

Rerata laju pertumbuhan spesifik kepiting bakau (S. serrata Forsskål, 1775) selama 35 hari (5 minggu) pada masingmasing perlakuan secara berurutan adalah perlakuan A sebesar 5,46+0,66\% per hari, perlakuan B sebesar 5,16 $\pm 0,52 \%$ per hari dan perlakuan $C$ sebesar $4,02 \pm 0,51 \%$ per hari.

\section{Rasio Konversi Pakan}

Rerata rasio konversi pakan kepiting bakau (S. serrata Forsskål, 1775) selama 35 hari (5 minggu) pada masing-masing perlakuan, yaitu: perlakuan A mempunyai

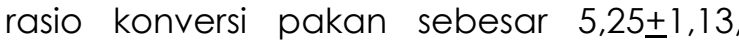

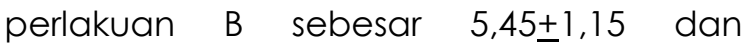
perlakuan $C$ sebesar $7,16 \pm 1,55$.

\section{Rasio Efisiensi Protein}

Rerata rasio efisiensi protein kepiting bakau (S. serrata Forsskål, 1775) selama 35 hari (5 minggu) pada masing-masing perlakuan, yaitu: perlakuan A mempunyai rasio konversi pakan sebesar 0,62 $\pm 0,13$, perlakuan $B$ sebesar $0,60 \pm 0,13$ dan perlakuan $C$ sebesar $0,46 \pm 0,11$. Hasil analisis dengan anova perlakuan ukuran pakan menunjukkan berpengaruh sangat nyata $(p \leq 0,01)$ terhadap laju pertumbuhan spesifik Kepiting bakau (S. serrata Forsskål, 1775). Hasil tersebut menunjukkan bahwa, pemberian pakan berupa pelet yang berukuran relatif lebih besar memberikan pengaruh yang lebih baik terhadap rerata laju pertumbuhan spesifik Kepiting bakau (S. serrata Forsskål, 1775). Hal ini diduga karena pola kebiasaan makan kepiting bakau dalam mendapatkan makanannya dengan cara mencapit pakan, sehingga pakan yang berukuran relatif lebih besar bisa dipegang dengan capit kepiting. Rangka (2007) yang menyatakan bahwa, kepiting bakau dalam pola kebiasaan makannya adalah dengan cara memegang pakan dengan capitnya sebelum dimasukkan ke dalam mulut. Sedangkan Kanna (2005) berpendapat, ukuran pakan untuk kepiting bakau perlu disesuaikan dengan kemampuannya dalam mencapit pakan.

Perbedaan laju pertumbuhan spesifik pada perlakuan juga didukung dengan perbedaan nilai konversi pakan dan efisiensi pemanfaatan protein. Efisiensi pemanfaatan protein berkaitan dengan efiesiensi suatu pakan terhadap pertumbuhan suatu biota. Laju pertumbuhan spesifik tertinggi pada perlakuan A didukung dengan nilai konversi pakan yang rendah dan pencapaian efisiensi pemanfaatan protein yang tinggi. Hal ini menunjukkan bahwa pada pakan perlakuan A dihasilkan efisiensi yang lebih baik terhadap pertumbuhan Kepiting bakau (S. serrata Forsskål, 1775) dibandingkan perlakuan lainnya.

Nlai efisiensi protein yang semakin tinggi menggambarkan bahwa kualitas pakan untuk suatu biota tertentu semakin 



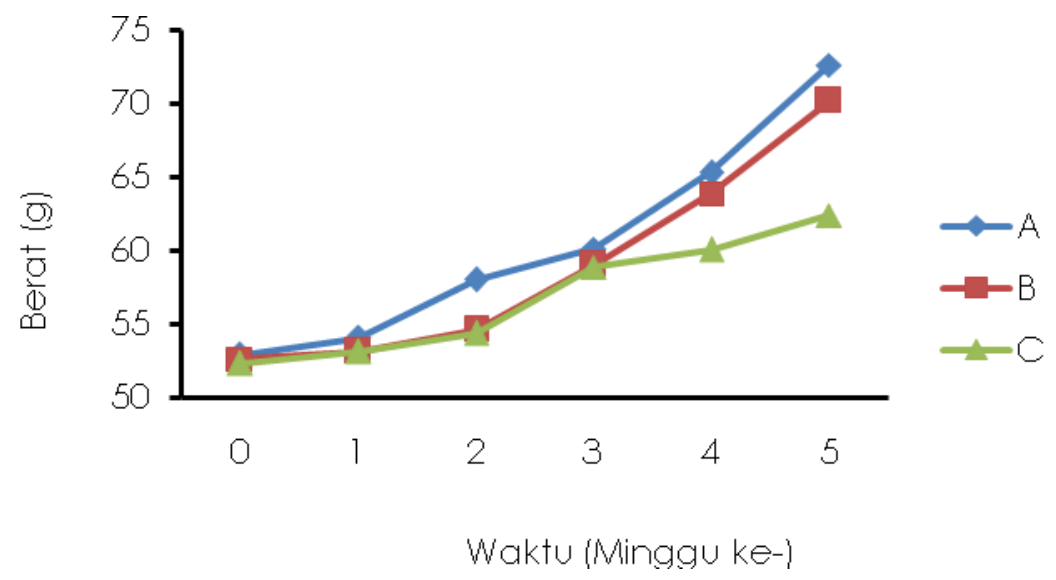

Gambar 1. Rerata Pencapaian Berat Kepiting bakau (S. serrata Forsskål, 1775) pada Pemberian Berbagai Ukuran Pelet Selama 35 Hari. Keterangan: $A=$ pelet $\varnothing \pm 10 \mathrm{~mm}, B=$ pelet $\varnothing \pm 5 \mathrm{~mm}, C=$ pelet $\varnothing \pm 1 \mathrm{~mm}$.

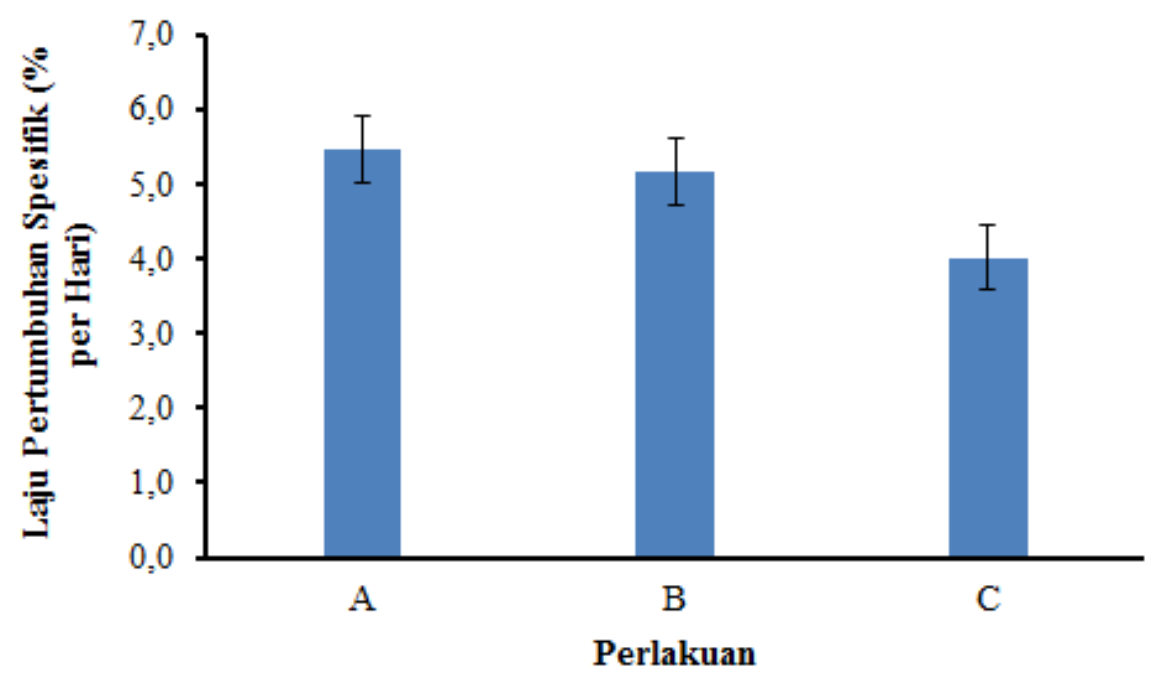

Gambar 2. Histogram Rerata Laju Pertumbuhan Spesifik (\% per hari) Kepiting Bakau (S. serrata Forsskål, 1775) pada Pemberian Pelet yang Berbeda Ukuran Selama 35 Hari. Keterangan: $A=$ pelet $\varnothing \pm 10 \mathrm{~mm}, B=$ pelet $\varnothing \pm$ $5 \mathrm{~mm}, \mathrm{C}=$ pelet $\varnothing \pm 1 \mathrm{~mm}$.

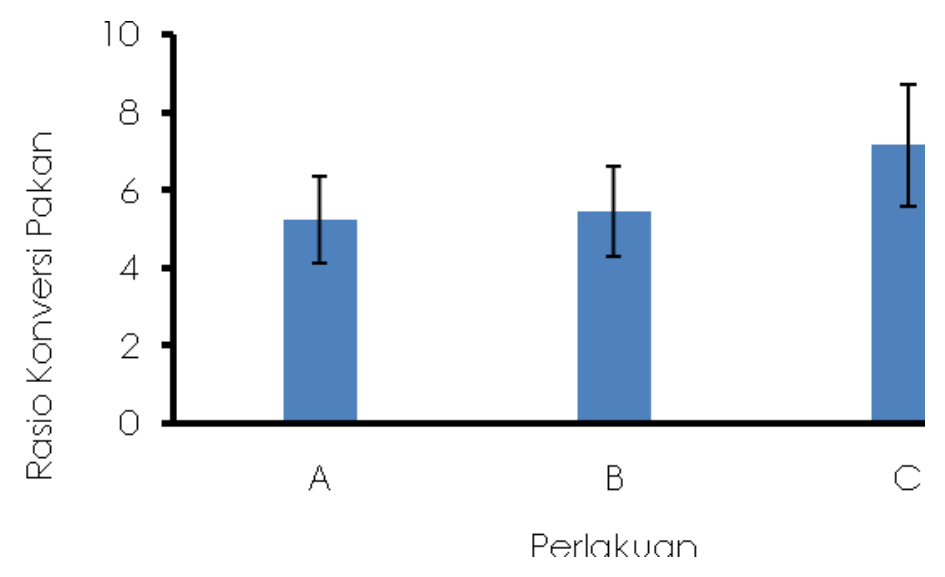

Gambar 3. Histogram Rerata Rasio Konversi Pakan Kepiting Bakau (S. serrata Forsskål, 1775) pada Pemberian Pelet yang Berbeda Ukuran Selama 35 Hari. Keterangan: $A=$ pelet $\varnothing \pm 10 \mathrm{~mm}, B=$ pelet $\varnothing \pm 5 \mathrm{~mm}, C=$ pelet $\varnothing \pm 1 \mathrm{~mm}$. 


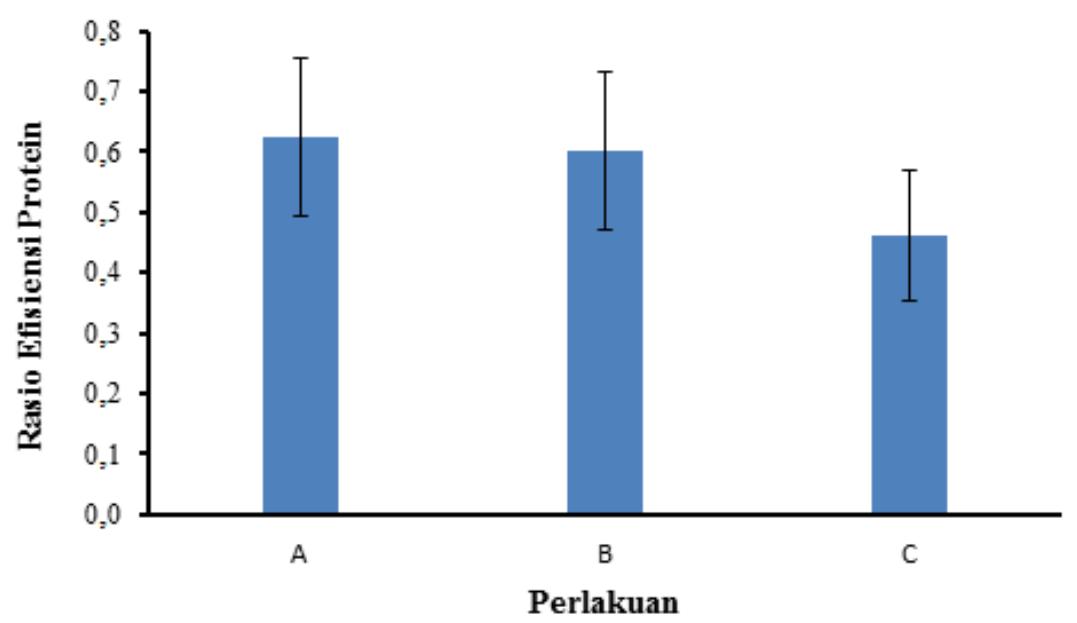

Gambar 4. Histogram Rerata Rasio Efisiensi Protein Kepiting Bakau (S. serrata Forsskål, 1775)pada Pemberian Pelet yang Berbeda Ukuran Selama 35 hari. Keterangan: $A=$ pelet $\varnothing \pm 10 \mathrm{~mm}, B=$ pelet $\varnothing \pm 5 \mathrm{~mm}, C=$ pelet $\varnothing \pm 1 \mathrm{~mm}$.

baik pula. Kualitas pakan yang semakin baik menunjukkan kecernaan ikan terhadap pakan tersebut semakin baik. Peningkatan kecernaan akan mengakibatkan nutrisi pakan semakin banyak diserap tubuh guna kebutuhan metabolisme dan pertumbuhan. Penggunaan bahan pakan yang mempunyai nilai kecernaan yang tinggi akan lebih efisien dalam meningkatkan pertumbuhan kepiting.

Pertumbuhan dapat terjadi apabila terdapat kelebihan energi melalui pakan yang dikonsumsi dikurangi dengan kebutuhan energi untuk berbagai aktivitas (Karim, 2007). Upaya pemberian pelet yang berbeda Ukuran secara tidak langsung memberikan perbedaan rerata jumlah energi yang masuk melalui pakan yang dikonsumsi oleh kepiting bakau. Pada penelitian ini, masing-masing perlakuan mempunyai perbedaan berat pakan per butir dan jumlah butir yang disesuaikan dengan jumlah pemberian pakan per harinya ( $10 \%$ biomassanya). Jika dilihat dari ukuran dan jumlah butir pakannya, perlakuan A membutuhkan energi lebih kecil dari pada perlakuan lain untuk proses mengambil pakan dan memasukkannya ke dalam mulut. Pada perlakuan ini, diduga energi yang dikonsumsi dari jumlah konsumsi pakan lebih besar dari pada energi yang dikeluarkan untuk semua aktivitasnya termasuk mengambil pakan.
Hal ini didukung oleh hasil analisis protein efisiensi ratio (gambar4), dimana pada perlakuan A dan B nilainya lebih besar dibandingkan dengan perlakuan $\mathrm{C}$. Hal tersebut menunjukkan bahwa pakan yang dikomsumsi oleh kepiting lenbih efisien.

\section{KESIMPULAN}

Berdasarkan hasil penelitian dapat disimpulkan bahwa, pemberian pelet dengan ukuran berbeda memberikan pengaruh sangat nyata $(p<0,01)$ terhadap laju pertumbuhan spesifik (SGR) kepiting bakau (S. serrata Forsskål, 1775). Laju pertumbuhan spesifik tertinggi dicapai oleh kepiting bakau yang diberi pakan pelet berdiameter pelet $\pm 10 \mathrm{~mm} \quad(5,42 \pm 0,64 \%$ per hari), dan terendah dicapai pada pakan berdiameter pelet $\pm 1 \mathrm{~mm}$ ( $4,02 \pm 0,51 \%$ per hari).

\section{DAFTAR PUSTAKA}

Aslamsyah, S. dan Fujaya, Y. 2009. Formulasi pakan buatan khusus kepiting yang berkualitas. Jurnal sains dan teknologi, 9(2): 133-141.

Djunaedi, A. 2008. Kematangan gonad kepiting bakau Scylla serrata pada pemberian pakan dengan komposisi dan ransum harian berbeda. Jurnal IImu Kelautan, 13(4):181-184. 
Fadnan, M., Iromo, H. dan Azis. 2010. Pengaruh padat tebar yang berbeda terhadap pertumbuhan dan kelangsungan hidup pada penggemukan kepiting bakau (Scylla sp.). Jurnal Harpodon Borneo, 3(2): 61-69.

Fujaya, Yushinta. 2010. Kepiting Komersial di Dunia: Biologi, Pemanfaatan danPengelolaannya. Yayasan Citra Emulsi. Makassar.

Huet, M. 1979. Text Book of Fish Culture, Eyre and Spottis. Woode Ltd, London, 294 $\mathrm{pp}$.

Jangkaru, Z. 1974. Makanan Ikan. Correspondence Course Center Direktorat Jendral Perikanan Departemen Pertanian, Jakarta, 72 $\mathrm{hlm}$.

Kanna, I. 2005. Budidaya Kepiting Bakau. Kanisius, Yogyakarta, $80 \mathrm{hlm}$.

Karim, M.Y. 2007. Pengaruh salinitas dan bobot terhadap konsumsi kepiting bakau (Scylla serrata Forsskål). Jurnal Saint \& Teknologi, 7(2): 85-92.

Overton, J.L. and R.K.U.D. Pushpakumara. 1999. Mud crab systems for smallscale aquaculture: thoughts and lessons colleted by DFID and FAO during 1999. In: Ultilizing Different Aquatic Resources for Livelihoods in Asia: A Resource Book, IRR and SMISLE, pp.56-62.

Rangka, N.A.2007. Status usaha kepiting bakau ditinjau dari aspek peluang dan prospeknya. Jurnal Neptunus, 14(1): 90-100.

Susanto, G. N. 2008. Peneluran kepiting bakau (Scylla sp.) dalam kurungan bambu di tambak berdasarkan pengamatan tingkat kematangan gonad. Seminar Hasil-hasil Penelitian dan Pengabdian Kepada Masyarakat dalam Dies Natalis Unila ke-42, Jurusan Biologi, FMIPA, Universitas Lampung, 300-309. 